\title{
りん酸形燃料電池のセル短絡運転技術の開発
}

$\begin{array}{llll}\text { 正 員 } & \text { 小川 } & \text { 賢 } & \text { (関西電力株式会社) } \\ \text { 非会員 } & \text { 森下 } & \text { 健治 } & \text { (関西電力株式会社) } \\ \text { 正 員 } & \text { 堀内 } & \text { 弘志 } & \text { (三菱電機株式会社) }\end{array}$

\section{Development of Detour Operation Method for PAFC Stack}

\author{
Masaru Ogawa Member, Kenji Morishita Non-Member (Kansai Electric Power Co.,Inc.) \\ Hiroshi Horiuchi Member, (Mitsubishi Electric Corp.)
}

\begin{abstract}
It has been developed the method to improve a fleet availability for PAFC power plant as on-site repairing operation. The detour operation from a defect cell in the stack has been investigated. The method of this is used a carbon block with some adhesive on the contact interface to form a electrical by-pass, thus the defect cell could be detoured from stack current path and low resistant path by the carbon block would be secured. Some improvement on the contact or fixation have been examined and the methods have been confirmed their life performances with bench scale cell tests. The results of these are discussed
\end{abstract}

キーワード: りん酸形燃料電池, セル補修技術, セル短絡技術, カーボン短絡板, 締め付け力

\section{1 まえがき}

りん酸形燃料䉓池スタックは、数百枚のセル(単電池) が電気的に直列に積層されて構成されている。このため、 1 枚でも不良セルが発生すると、当該セルの腐食が急速に 進展し、周囲のセルにも損傷が拡大するので、セル保護上 運転停止とせざるを得ない。

セル特性の回復が不可能なトラブルが発生すれば、従来 は燃料電池本体をメー力工場まで輸送して修理を行ってい たが、復旧までにかなりの期間を要し、燃料電池の実用 化を阻害していた。この問題を解消すべく、現地で容易か つ確実に不良セルを短絡して、発電を継続できる技術を考 案した。本論文では小型セルを使用した短絡試験の結果を 報告する。

2 従来のセル短絡技術 七ルに回復が不可能な トラブルが発生しても、電池スタックの発電を継続できる セル短絡技術が既に数種類提案されている。しかし、現在 実用化されているものはなく、以下に既存のセル短絡技術 の方法と問題点について説明する。

〈2.1〉金風製短絡板による不良セル短絡方法ここ方 法は [特開平 4-366561] (1)で公開されており、図 1 に示 すように、不良化したセルの端部に金属製短絡板を挿入し、
ボルトなどで固定する事により不良セルを電気的に短絡さ せ、電気的にバイパスして発電を継続する方法である。

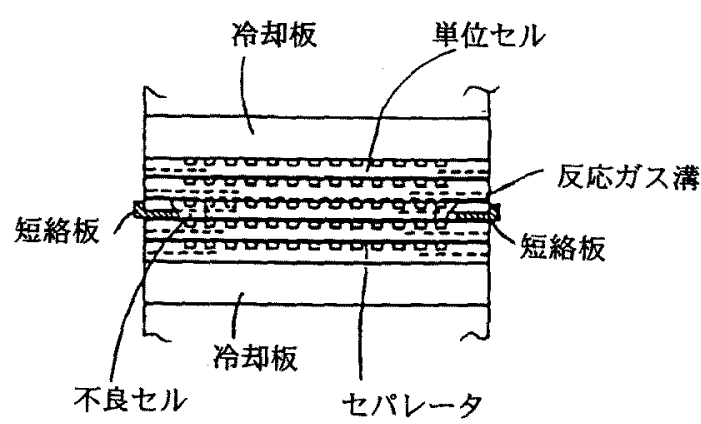

図 1 金属製短絡板による不良セル短絡方法模式図

Fig.1 Schematic structure of the cell detour operation method used metal plate

しかしこの方法には下記のような問題点がある。短絡板 に金属を用いているために、りん酸のように腐食性の高い 電解質を用いる場合には、容易に金属短絡板が腐食されて しまい、腐食による接触抵抗の增大と長期の信頼性確保が 困難である。また、短絡板の固定材料にも表面保䜕のない 金属を用いているため、りん酸により腐食し、電気的接触 面の密着性を保持することが出来なくなる。

〈2.2〉カーボン製短絡板による不良セル短絡方法ここ の方法は[実公昭 63-17165] (2) で公開されており、図2 
に示すように、耐りん酸腐食性の高いカーボン材を使い、 カーボン板を不良セルの上下の冷却板に嵌め込み、不良セ ルを電気的に短絡させる万法である。

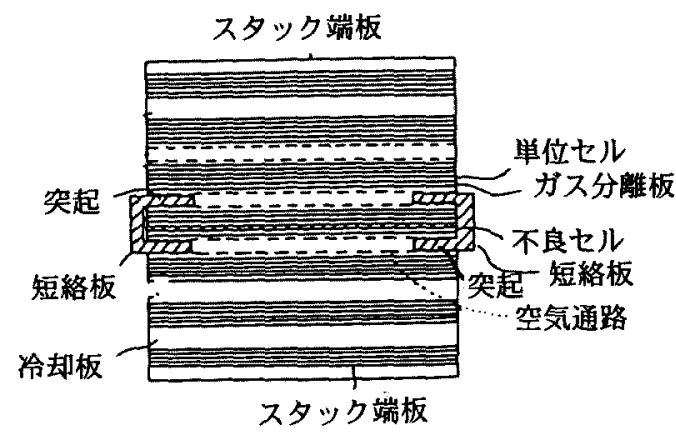

図2 カーボン製短絡板による不良セル短絡方法模式図

Fig.2 Schematic structure of the cell detour operation method used carbon plate

しかし、この方法にも下記に示す問題点がある。

(1)セルは多数積層している構造のため、長期的には重量 による圧縮変形を起こし泠却板間の寸法が縮まる。本方式 では短絡板の固定を凹凹による嵌合としているため、セル 压縮変化による㐫力で短絡板に割れが生じる恐れがある。

(2)短絡治具の固定は嵌着に頼るが、冷却板間距雄は個々 のセルで異なり、公差も極めて少なく、現物合わせをして カーボン板の製作を行う必要がある。このため、実プラン トの運転現場での短絡技術としては作業の容易さに欠ける。 このように、従来のセル短絡技術では、りん酸腐食や力 一ボンブロック材に割れが発生する恐れがあり、実用化す るには今後の改良が必要である。

\section{3 新しい短絡技術}

新しい短絡技術は上記のような問題点を解決することを 目指した。このため、短絡板には耐食性の高い材料を使用 し、泠却板と短絡板との取付方法としては現地での作業性 の容易な方法とした。さらに電気導電性を確実に確保する ために短絡治具とセル間の間隙を充填する素材を使用する こととした。上記コンセプトで短期間で処理できることを 目的とし、新しいセル短絡技術は下記に示す特徴を持つ。

(1)短絡板の材質には、りん酸による腐食性が低いカーボ ン材を用い、不良セルを含むセルグループの冷却板の側面 に接触するように配置した。

(2)短絡板の取付方法としては、セルのガス溝を通した十 数本のワイヤやシャフトの端部にねじ部を設け、ねじ部の ナットの締付力を利用し、短絡板どうしが引つ張り合って 取付ける万法とした。この方法は、電気的接触面の密着性 確保と同時にセル積層方向の圧縮変形に対しても短絡板が 割れるような応力を受けないフレキシブルな構造である。

(3)セル温度変化によるワイヤやシャフトの熱延びによる 短絡板締め付け圧の低下防止のために、バネをワイヤやシ ヤフトに組み込んだ。
(4)冷却板と短絡板間の電気的な接触を確実にするため、 導電性の紛状体またはペースト状の接着剂を充填した。 (5)短絡板取付用部材には、耐高温、耐腐食性の高いフッ 素樹脂の被覆パイプやフッ素樹脂をコーティングしたステ ンレス製ワイヤやシャフトを用いた。

本方法による不良セル短絡方法の模式図を図 3 に示す。

図 3 は長尺のシヤフトとナットを用いて短絡板を取付け る方法である。不良セルを含む泠却板の両側を短絡板で挟 み電気的にパイパスする。短絡板には細いシャフトを一定 間隔で通し、空気溝を貫通させて反対側の短絡板を通して ネジで締め付け、短絡板を取付ける。シャフトはりん酸腐 食を防止するためにフッ素樹脂チューブの中を通すかある いはフッ菜樹脂でコーティングをして、りん酸蒸気と直接 接触しないようにしている。シャフトの代わりにワイヤー の線材を使用することも可能であるが、シャフトは強い締 め付け力が得られるので、大面積セルの短絡に適している。 このため、本論女では強度の大きいシャフトを選定して赛 験をした。

短絡用カーボン板

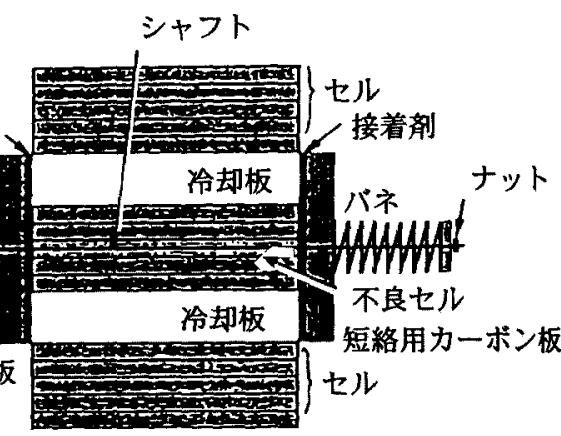

図 3 新しいセル短絡板取付方法模式図

Fig.3 Schematic structure of new type cell detour operation method

\section{4 要素技術開発}

〈4. 1〉接着到の材料選定冷却板之短絡用カーボン 板の接触部に塗布する接着剤は接触抵抗を低減させる重要 な役割を持つ。このため、りん酸形然料電池に実績のある 材料から電気伝導性の良い材料としてカーボンを主成分と したコンパウンド系接着剈とカーボン粉系有機接着剤を選 定した。選定した材料の特徵を以下に示す。

・コンパウンド采接着剂(コンパウンド材)：電池冷却水管 を泠却板に装着時、泠却水管の周囲に充填する接着剤。主 成分は黒鉛粉で溶剂に混ぜて使用する。

・カーボン粉系有機接着剂：各種の計測線の接着用に使用 する接着剤。電気伝導性が高く、耐りん酸腐食性も高い。

接着剂を選定するために図 4 に示す接触抵抗試験を実施 した。接触抵抗試験ではカーボン板 1 と 2 、カーボン板 2 と 3 の間にそれぞれの接着剤を挟み、1 $\mathrm{A}$ の電流を流して 
ミリオームメータで各カーボン板間の電気抵抗を測定し た。カーボン板の寸法は $(150 \mathrm{~mm} \times 150 \mathrm{~mm} \times 5 \mathrm{mmt})$ で接 着剤はペースト状のものを塗布するために、愿さは数百ミ クロン程度である。

試験結果を表 1 に示す。試験結果より、接着郕としては 抵抗值の低いコンパウンド系接着刜を選定した。

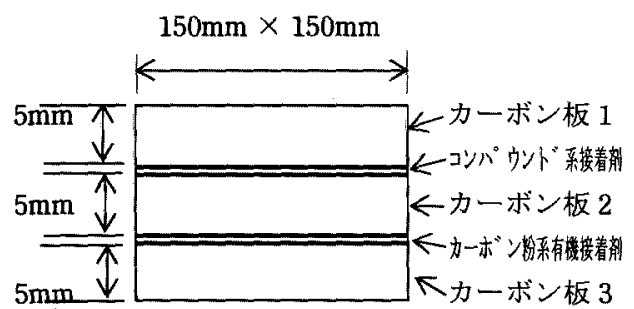

図 4 接触抵抗試験要領図

Fig.4 Schematic structure of contact resistance test

表 1 接触抵抗試験結果

Table1. Results of contact resistance test

\begin{tabular}{|c|c|}
\hline 接着剂 & 抵抗値 $(\mathrm{m} \Omega)$ \\
\hline コンパウンド系接着剤 & 0.08 \\
\hline カーボン粉系有機接着郕 & 18.27 \\
\hline
\end{tabular}

〈4. 2〉ヒートサイクル試験＼cjkstart燃料電池システムの起 動停止に伴うヒートサイクル時のセルの膨張と伸縮に接着 㓮が追従できるかの試験を行った。ヒートサイクル試験に 使用した試験体を図 5 に示す。カーボン板の寸法、材質は 接触抵抗試験と同じである。カーボン板間には不良セルを 模擬したテフロン板を挿入した。短絡板とボルト間には血 バネを入れて、カーボン板と短絡板に常に一定面圧が作用 するようにし、常温と $180^{\circ} \mathrm{C} の$ 間でサイクル運転を繰り返 して抵抗值の変化を測定した。

試験結果を表 2 に示す。試験前には $97.0 \mathrm{~m} \Omega$ と大きい値 であったが試験を開始すると接触面のなじみが生じ、抵抗 值住 $14.0 \mathrm{~m} \Omega$ 程度に安定した。

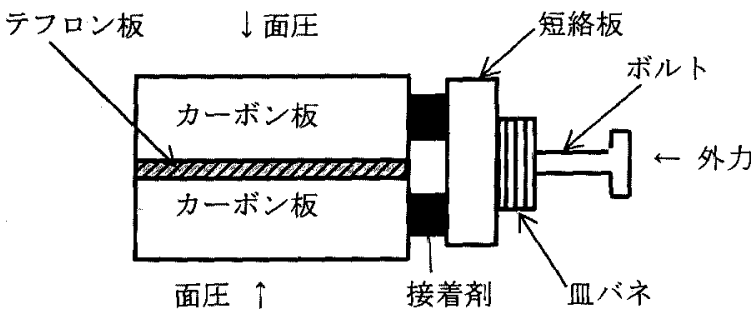

図 5 ヒートサイクル試験要領図

Fig.5 Schematic structure of heat cycle test

表 2 ヒートサイクル試験における抵抗変化

Table2. Change of Resistance at heat cycle test

\begin{tabular}{|l|c|c|c|c|}
\hline $\mathrm{t}-\mathrm{H}$ 亿似回数 & 試験前 & 1 回 & 2 回 & 3 回 \\
\hline 抵抗 $(\mathrm{m} \Omega)$ & 97.0 & 14.0 & 14.1 & 14.9 \\
\hline
\end{tabular}

〈4.3〉要素試験の結論要素試験により、短絡に必要 な条件として下記事項を確認することが出来た。

(1)泠却板と短絡板の接着剂としては、黒鉛を主成分とした コンパウンド材が抵抗が小さく優れていた。

(2)短絡板をボルトによって冷却板に圧着させ、ボルトと短 絡板間にバネを挿入することにより、ヒートサイクルに対 しても抵抗值の変化がなく、压着力を維持出来た。 (3)抵抗值 $14.0 \mathrm{~m} \Omega$ はまだ大きいが、短絡板とボルト間の バネにより常に一定面圧をかけ、締め付け力を強化すれば 抵抗値を下げられることが分かった。

\section{5 小型セルの短絡試験 1}

〈5.1〉短絡試験 1 の試験条件 七ル短絡技術の効果 の確認のために $150 \mathrm{~mm} \times 150 \mathrm{~mm}$ の小型セルを 5 セル積 層したブロックを使用して、定電流を流してセル短絡試験 を実施した。図 6 に短絡試験 1 のセル積層関係を示す。こ の試験では下記の点に改良を加えて実施した。

(1)空気側の出入口に 2 枚の短絡板を装着して、シャフトを 空気極の多孔体の溝を通してナットで緊縛した。 (2)短絡板、接着剤、冷却板の接着性を高めるために、短絡 板とナット間にバネとワッシャを㨉入した。 (3)シャフトの径は空気满を通すため、シャフト径は $1 \mathrm{~mm}$ とし先端にはナット用のネジをきった。また、りん酸によ る腐食防止用としてテフロンコーティングをした。 (4)バネ、ワッシヤ、ナットはりん酸による腐食を防止する ために空気入口側に設けた。空気出口側は止め血を溶接し、 テフロンコーティングをした。

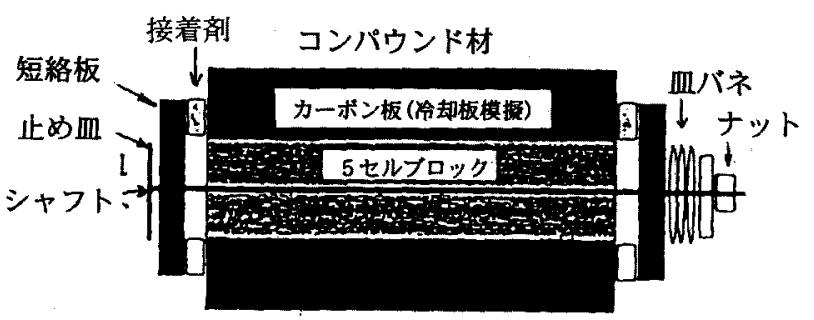

図 6 短絡試験 1 のセル積層関倸図

Fig.6 An assemble for detour operation test No1 短絡試験 1 では 2 種類の試験を実施した。一つはこれま での運転経験から、セル電圧が低下したセルでも電流密度 を下げるとセル電圧が回復するケースがある。これは電流 密度が低下するとセル面内での電流密度分布が変わり、セ ルの健全部のみで負荷を負担できるためと推定される。こ のようなセルでは電流密度を低くすれば発電継続が可能上 考えられる。このため、短絡試験 1 - 1 (発電そード)で は、 5 セルは短絡板により電気的に短絡するとともに、セ ルは発電もできるように燃料ガスと空気を供給して、短絡 板とセル発電との相互作用の影響を把握する目的で実施し 
た。セル動作条件としては、燃料極には模擬改質ガス(水 素 $80 \%$,二酸化炭素 20\%) を、空気極に注空気を供給し、 セルは小型のために冷却なし、七ル動作温度は $200^{\circ} \mathrm{C}$ 、水 素利用率 80\%、酸素利用率 $60 \%$ とした。ただし、小型セ ルのため短絡板の取付上、マニホールドの構造的制䄪から 各セルに均等な量の空気の分配ができなかったために、各 セルへの供給量に差が生じた。

もう一つは、ガスクロス等が発生しているセルでは、然 料ガスと空気を供給すると直接反忘をして燃焼する后険性 がある。このような不良セルには燃料ガスや空気が入らな いようにガス溝や空気溝を塞ぎ、窒素等の不活性ガスで密 閉してセル短絡部に電流を流す必要がある。このため、短 絡試験 1-2(密閉モード)では5セルはカーボン板により 短絡し、セルの燃料極や空気極には窒素ガスを封入して、 発電できない状態で試験した。

試験条件を表 3 に示す。なお、七ル電圧の測定はセル端 部に白金線を固着して計測した。

\section{表 3 七ル短絡試験の試験条件}

Table3. Test condition of cell detour operation test

\begin{tabular}{|c|c|c|}
\hline 試験項目 & $\begin{array}{l}\text { 短絡試験 } 1-1 \\
\text { (発電モード) }\end{array}$ & $\begin{array}{r}\text { 短絡試験 } 1-2 \\
\text { (密閉モード) }\end{array}$ \\
\hline 燃料極 & 模擬改質ガス & 窒素ガス \\
\hline 空気極 & 空 気 & 耋素ガス \\
\hline 負荷電流 & $\begin{array}{c}10 \mathrm{~A} \\
\left(100 \mathrm{~mA} / \mathrm{cm}^{2}\right)\end{array}$ & $\begin{array}{c}10 \mathrm{~A} \\
\left(100 \mathrm{~mA} / \mathrm{cm}^{2}\right)\end{array}$ \\
\hline
\end{tabular}

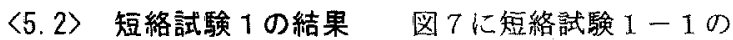
試験の結果示す。電圧は 5 セル合計の電压である。反忘 ガスが供給されているために起電力が生じており、短絡部 の電位差はプラスの電圧が発生しているが、5セル分の電 圧は出ていない。この方法では、セル面内の一部に電圧低 下が生じているセルでも健全部は発電が可能であり、短絡 板を取付けると電流の一部は短絡板を流れる。このため、 短絡板とセル健全部の双方で電流を負担することとなり、 セル不良部の損傷を加速させることなく、定格負荷に近い 発電が可能となる。

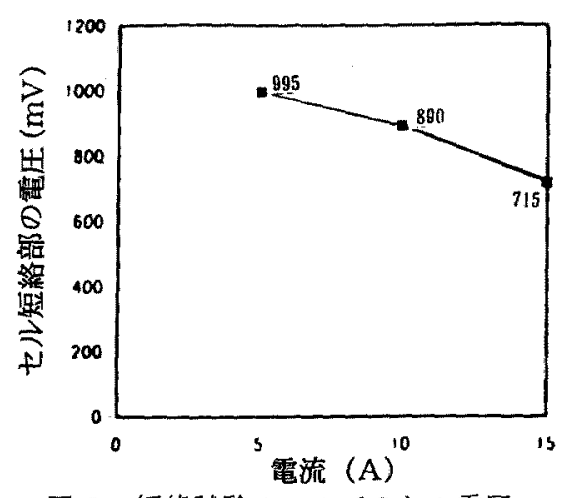

図 7 短絡試験 1-1でのセル電圧

Fig. 7 Cell voltage at cell detour operation test Nol-1

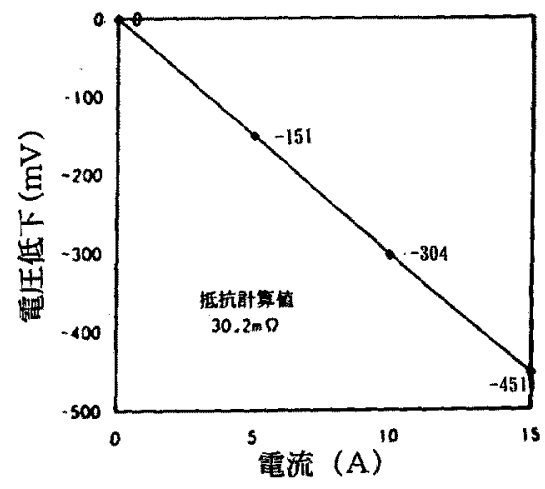

図 8 短絡試験 1 -2での短絡部の電圧低下

Fig.8 Voltage drop of carbon-plate at cell detour operation test No1-2

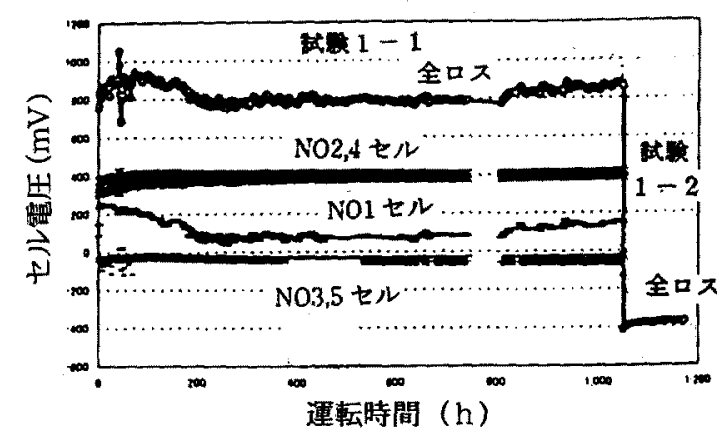

図 9 短絡試䟭条件 1-1, 1-2で安定性試験

Fig.9 Stability of voltage at cell detour operation test No1- 1 and No1-2

セル電圧が逆電圧になっている場合は不良セルの腐食が 進行する恐れがあり、セル発電と短絡板との併用方法は採 用できない。また、長期間にわたって併用して発電する埸 合の信頼性についても今後の検証が必要である。

図 8 に短絡試験 1-2の短絡試験の結果を示す。この場 合はセルに起電力が発生しないために、オームの法則に従 い、負何電流と電圧降下は面線関倸で表せた。

図 9 に短絡試験 $1-1$ および短絡試験 1-2での短絡状 態の安定性の試験結果を示す。短絡試験 $1-1$ を 1,000 時 閒強実施し、その後改質ガスや空気を窒素ガスに変えて短 絡試験 1 -2 150 時間害施した。短絡試験 1-1では セルへの然料ガス、空気の等配性が不十分なためにセル電 压に差が生じているが、最低でもゼロ電圧で、鱼の電圧は 発生していない。しかし、短絡試験 $1-2$ では負の電圧に なり、短絡した 5 セルは抵抗体としてのみ機能している。 しかし、双方の試験とも短絡状態の経時的な変化はなく、 試験後のセル解体結果からもセル面、シャフト、ナット等 に異常な損傷は認められなかった。

\section{6 小型セルの短絡試験 2}

〈6.1〉短絡試験 2 の試験条件短絡試験 1 により 
ル短絡効果の目処が得られた。このため、実スタックの発 電状態を模擬し、正常セルと短絡セルグループとを電気的 に直列に連結し、短絡部が周边セルに及ぼす影響を把握す る試験をした。これは短絡板に電流が流れると電流がセル の両サイドに偏流するために、短絡したセルグループの上 ・下で接する正常セルの電流分布が影響を受け、特暴な現 象が発生しないかを確認するためである。図 10 に試験体 のセル積層関係を示す。1枚の正常な単セルの下に5セル (不良セルが含まれていると仮定した)を短絡したセルグル ープを直列に接続した。また、起電力の発生と短絡ブロッ クへのガスリークを防止するために、短絡ブロック端部の ガス通路は全てコンパウンド材により塞ぎ、ガスや空気の 進入をなくした。この短絡試験装置の単セルを発電して短 絡部の抵抗を测定した。

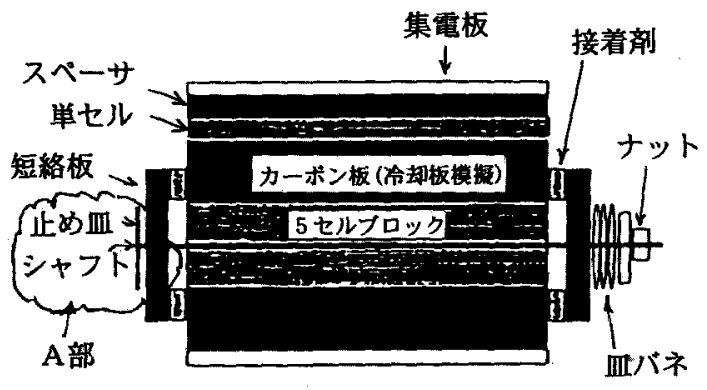

図 10 短絡試験 2 でのセル積層関保図

Fig.10 An assemble for cell detour operation test No2 また、要素試験よりセル短絡時の電気抵抗を低下させる にはカーボン板の締め付け力を維持することが重要である ことが分かっている。このため、3 種類の締め付け方法に ついて試験を行った。表 4 に 3 種類の締め付け方法の特徽 と、図 10 の A 部の扩大図を示す。

表 4 短絡試験 2 のカーボン板締め付け構造図 Table4. Structures of carbon plate tied-up part at detour operation test $\mathrm{No} 2$

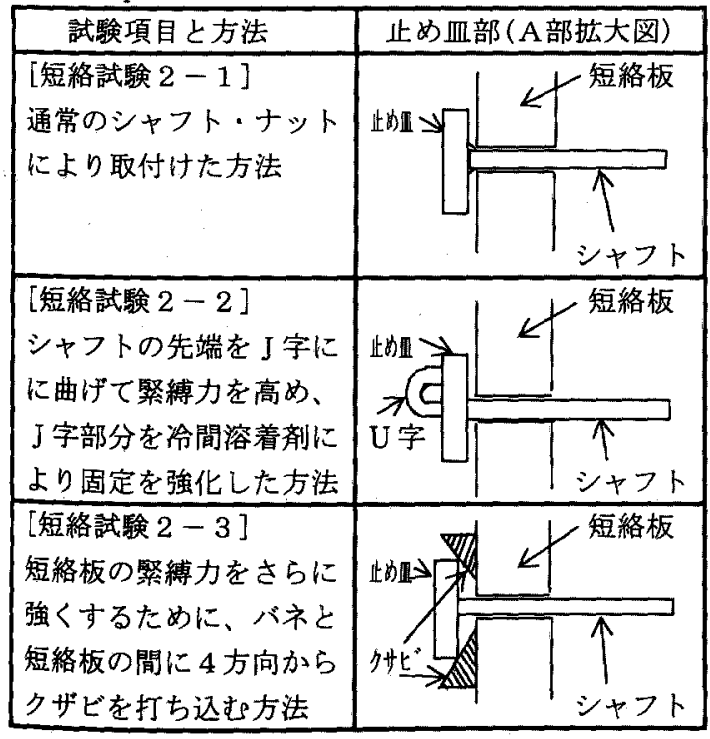

セル仕様や試験条件は短絡武験 1 と同じで、定電流を流 して実施した。各方法の特徵としては

- 短絡試験 2-2はシャフト先端にネジ切り加工や止め血 溶接の必要がなく、低コスト化が可能。

・短絡試験 2-3はバネの圧縮力の調整が可能となり、組 立時から短絡板と冷却板間の高い繁縛力を維持することが 可能である。また、短絡抵抗をさらに下げるために、空気 の出入口、然料ガスの出入口の4 面に短絡板を装着した。

〈6.2〉短絡試験 2 の結果図 11 に短絡試験 $2-1$ の試験結果を示す。 5 セル短絡部での電圧低下が大きく、 電流は 10 A以上では電子負荷装置のリミッターがかかる ために電流密度は $100 \mathrm{~mA} / \mathrm{cm}^{2}(10 \mathrm{~A})$ までしか取ること

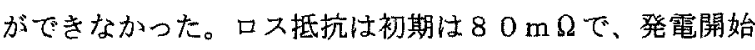
後 70 時間経過後には抵抗に増加傾向が現れた。その後、 電流密度を徐々に下げたが、発電後 100 時間で $100 \mathrm{~m}$ $\Omega$ に增加し、電流密度も低下傾向が続いたために 180 時間 で試験を終了した。この原因は、接着剤であるコンパウン ド材が硬化により寉み、短絡板と泠却板閒の接着性が低下 したことと、温度変化によりシャフトとナットの緊縛力が 弱まったためと考えられる。

図 12 に短絡試験 2-2の試験結果を示す。短絡部の口 ス抵抗は 100 時間の発電試験によってもほとんど変化が なく、空気入口側ではダブルナットの使用上空気出口側で は J字固定法を採用することにより、短絡板と伶却板間の ネジの緊縛力を強めた効果が確認できた。しかし、抵抗値 の值そのものは $200 \mathrm{~m} \Omega$ とまだ大きかった。

図 13 に短絡試験 $2-3$ の試験結果を示す。短絡試験 2 -1、短絡試験 $2-2$ では短絡部のロス抵抗が $100 \mathrm{~m} \Omega$ 〜 $200 \mathrm{~m}$ 囚のレベルにあったために、電流密度も75 $\mathrm{mA} / \mathrm{cm}^{2} \sim 1000 \mathrm{~mA} / \mathrm{cm}^{2}$ までしか発電ができなかった。 このため、短絡試験 $2-3$ では短絡板を燃料ガス側にも装 着した。その結果、短絡試験 $2-3$ での短絡抵抗は初期で $23 \mathrm{~m} \Omega 、 30$ 時間の発電後には $21 \mathrm{~m} \Omega$ 迄低下し、電流 密度は $300 \mathrm{~mA} / \mathrm{cm}^{2}$ まで取れるようになった。発電時間 は400時間を越えたが、発電時閒が 200 時間を超えた 頃から徐々にロス抵抗の增加が認められるようになった。

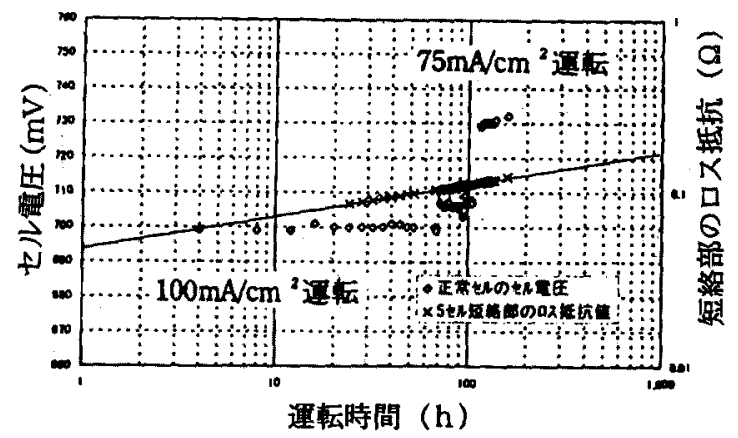

図 11 短絡試験 2-1の試験結果

Fig.11 Result of cell detour operation test No2-1 


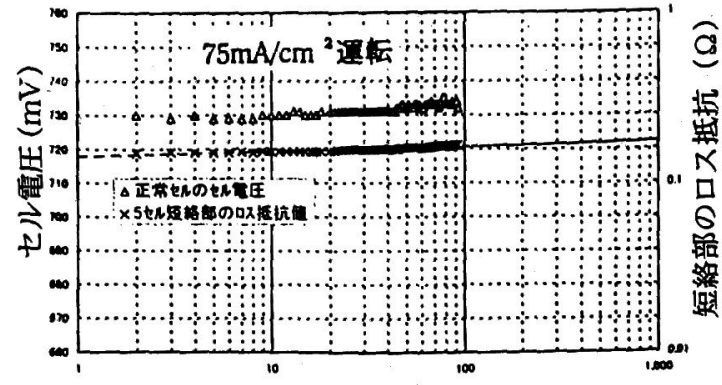

運転時間 (h)

図 12 短絡試験 2-2 の試験結果

Fig. 12 Result of cell detour operation test No2-2

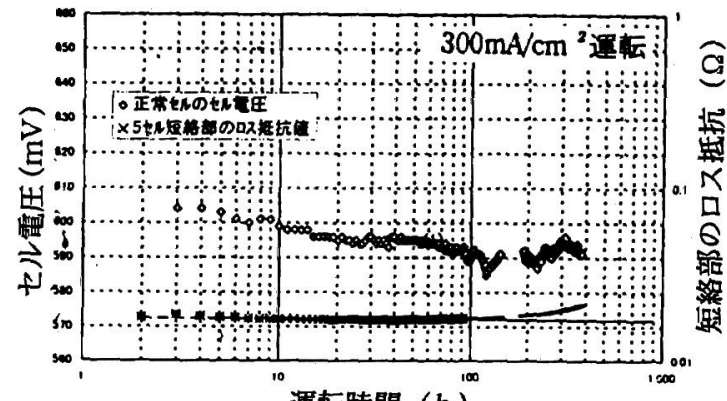

運転時間 $(h)$

図 13 短絡試験 2-3の試験結果

Fig. 13 Result of cell detour operation test No2-3 これはバネによる締め付け力が不十分になったためと予 想される。

単セル電圧の測定結果からは、発電時間も短いがセル電 圧の急速な低下はなく、電流の偏流の影響は認められなか った。

\section{7 まとめと今後の課題}

セルの短絡試験により、セル短絡方法の大きい課題は (1)りん酸腐食の生じない短絡板材の採用

(2)短絡板の取り付け方法

(3)短絡板と冷却板間の密着性と締付力

が重要であることが分かった。このための具体的な固定方 法として、本研究で下記方法が効果があることが判明した。

・不良セルを含むセルグループの燃料ガスと空気の出入口 の4 面に短絡板を装着する。

・りん酸腐食防止のためシャフトをテフロンコーティング する。

・短絡板と冷却板の緊縛力を高めるため、シャフトと短絡 板間にクサビを打ち込む等、締め付け力を調整できる方法 が有効である。

新しい短絡技術は冷却板の切削加工がないため電池本体 を傷つけることなく、より確実な修復が可能になった。こ

の方法により、特性不良セルが発生しても、現場で速やか に応急修復をして運転を再開出来ることが可能となり、補 修期間や費用を少なくすることができる。

しかし、この短絡方法を実用化するには実機レベルのセ ルサイズに適応して試験する必要がある。このためには、 抵抗を数 $\mathrm{m} \Omega$ レベルまで下げ、また、バネの弾性に耐えら れるボルトの選定や締め付け力を強化する有効なクサビの 形状選択等の課題が残されている。また、その後、実プラ ントに適応して、その効果と安全性を評価する必要がある。

(平成 11 年 6 月 11 日受付, 同 11 年 9 月 14 日再受付)

文 献

（1）田中英樹 [特開平 4-366561：東芝]公開特許公報 (A)

(2) 井出正裕、田島収、三宅泰夫[実公昭 63-17165：三洋 電機]実用新案公報 $(\mathrm{Y} 2)$

(3) 三好英明 [特開平 3-226973：三菱電機] 公開特許公報 (A)

（4）堤泰行、幹淳、山口雅教、難波「りん酸形燃料電池に おけるセル内局部短絡の検出法」T.IEE japan ,Vol111-B,No.11,91

小”川蜸（正員）1949年 3 月 9 日生。

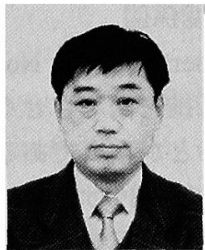
1972 年 3 月大阪府立大学機械工学科卒 業。同年 4 月関西電力（株）入社。 1982 年より総合技術研究所で燃料電池 開発研究に従事。主としてりん酸分散 配固型を担当。

森下 健治

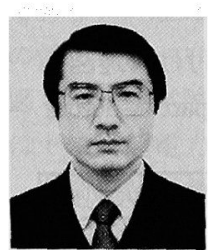

堀内 弘志

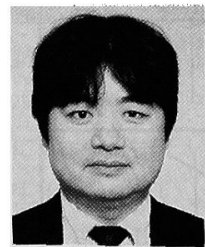

（非会員）1954 年 2 月 28 日生。 1974 年 3 月神戸市立工業高等專門学校 電気工学科卒業。同年 4 月関西電力 (株) 入社。1986 年より総合技術研究所で 燃料電池開発研究に従事。主としてりん 酸オンサイト型を担当。

(正員) 1959 年 9 月 22 日生。 1984 年 3 月横浜国立大学大学院修士課 程エネルギー材料専攻終了。同年 4 月三 菱電機 (株) 入社。主としてりん酸形燃 料電池の開発、研究に従事。 